\title{
Wpływ suplementacji diety selenem na przebieg autoimmunologicznego zapalenia tarczycy - przegląd badań klinicznych przeprowadzonych w populacji europejskiej
}

Jadwiga Kryczyk-Kozioł*, Paweł Zagrodzki, Paweł Paśko

Zakład Bromatologii Collegium Medicum Uniwersytetu Jagiellońskiego, ul. Medyczna 9, 30-688 Kraków

Abstrakt

Wiele obserwacji wskazuje na zależność między zmniejszonymi zasobami selenowymi organizmu a różnymi schorzeniami tarczycy, w tym także autoimmunologicznym zapaleniem tarczycy (AZT). W większości prac poświęconych temu zagadnieniu zmiana stężenia przeciwciał anty-TPO była główną miarą oceny skuteczności suplementacji selenem (Se) diety pacjentów z AZT. Stężenie przeciwciał anty-TPO ma wpływ na intensywność nacieków limfocytarnych w gruczole tarczowym i stopień jego uszkodzenia, dlatego zmniejszenie ich stężenia w wyniku zwiększonego spożycia Se może się przyczynić do skuteczniejszego leczenia AZT. W części prac omówionych w artykule ewaluacja immunoregulacyjnego działania Se w przebiegu AZT została rozpatrzona w odniesieniu do szerszego zakresu parametrów biochemicznych i immunologicznych (głównie dotyczy to zmian w wytwarzaniu cytokin i chemokin). Wielu autorów potwierdziło wpływ Se na zmniejszanie stężenia przeciwciał anty-TPO, jednak wyniki wszystkich prac nie są jednoznaczne. Przyczyną rozbieżności może być odmienny stopień wysycenia tarczycy Se i jodem w różnych grupach pacjentów, różny stopień zaawansowania choroby, różne dawki Se podawanego pacjentom, stosowanie lub niestosowanie jednoczesnej terapii L-tyroksyną oraz polimorfizmy pojedynczych nukleotydów (SNP) występujące w genach kodujących poszczególne selenobiałka.

Na podstawie dostępnej literatury można wnioskować, iż zagadnienie dotyczące roli Se w AZT jest nadal słabo poznane. Istnieje potrzeba kontynuowania badań oceniających wpływ suplementacji diety Se na przebieg tej choroby, które powinny obejmować poza anty-TPO inne parametry kliniczne. Dopiero wyniki tak szeroko ujętych badań mogą być pomocne w formułowaniu nowych wytycznych dotyczących wspomagania leczenia przez odpowiednią modyfikację diety

Słowa z uwzględnieniem suplementacji Se.

kluczowe

autoimmunologiczne zapalenie tarczycy • choroba Hashimoto • niedoczynność tarczycy• selen • badania kliniczne

Otrzymano: 22.09.2020, Zaakceptowano: 08.07.2021

Abstract

Many observations indicate the existence of a relationship between reduced selenium status in the body and various thyroid diseases, including autoimmune thyroiditis. In most studies devoted to this issue, change in concentration of anti-TPO antibodies was the main measure of the effectiveness of selenium supplementation in patients with autoimmune thyroiditis. The concentration of anti-TPO has an impact on the intensity of lymphocytic infiltration in the thyroid gland and the degree of damage to this gland; therefore, reducing their concentration as a result of increased selenium consumption may contribute to more effective treatment of autoimmune thyroiditis. In some works, the evaluation of immunoregulatory effect of selenium in the course of autoimmune thyroiditis was considered in relation to a wider range of biochemical and immunological parameters (mainly changes in the production of cytokines and chemokines). Many authors have confirmed the effect of selenium on reducing the concentration of anti-TPO, but pooled results of all the studies are ambiguous. The discrepancy may have been caused by a different degree of saturation of the thyroid with selenium and iodine in patients, a different severity of the disease, different doses of selenium administered to patients, the use or non-use of simultaneous therapy with L-thyroxine, and single nucleotide polymorphisms (SNPs) occurring in genes encoding particular selenoproteins.

Based on literature, it can be concluded that the issue concerning the role of selenium in autoimmune thyroiditis is still poorly understood. There is a need to continue research evaluating the effect of selenium on the course of this disease, which should include also other parameters apart from anti-TPO. The results of such extensive research may be helpful in formulating new guidelines for supporting treatment by appropriate modification of diet, including selenium supplementation.

Keywords

autoimmune thyroiditis • Hashimoto's thyroiditis $•$ hypothyroidism $•$ selenium $•$ clinical trials

Received: 22.09.2020, Accepted: 08.07.2021 
Choroba Hashimoto, nazywana także przewlekłym autoimmunologicznym zapaleniem tarczycy lub przewlekłym limfocytarnym zapaleniem tarczycy, jest główną przyczyną rozwoju niedoczynności tarczycy. W jej przebiegu pojawiają się zmiany w obrębie tkanki gruczołu tarczowego, m.in. rozlane nacieki limfocytarne, destrukcja tyreocytów i zwłóknienia. Rozpoznanie choroby Hashimoto ustala się zwykle na podstawie obniżonej echogeniczności miąższu tarczycy w badaniu ultrasonograficznym, obecności autoprzeciwciał przeciwtarczycowych przeciw peroksydazie tarczycowej (anty-TPO) i przeciw tyreoglobulinie (anty-TG) oraz wielkości stężenia hormonu tyreotropowego (TSH) i hormonów tarczycy w surowicy krwi. Dotychczasowy schemat leczenia pacjentów z tą chorobą opiera się na

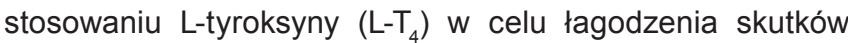
niedoczynności tarczycy (lub subklinicznej niedoczynności tarczycy) i/lub zmniejszenia objętości tarczycy. Proces ten zachodzi przez zmniejszanie stężenia TSH we krwi [1, 2, 3].

Wiele obserwacji wskazuje na zależność zmniejszonych zasobów selenowych organizmu a różnymi schorzeniami tarczycy [4, 5, 6]. W szeroko zakrojonych badaniach epidemiologicznych przeprowadzonych w prowincji Shaanxi, położonej w północno-środkowej części Chin, zaobserwowano, iż niski poziom zasobów selenowych w organizmie może być związany ze zwiększonym ryzykiem chorób gruczołu tarczowego, w tym AZT. Teren prowincji Shaanxi charakteryzuje się bardzo dużym zróżnicowaniem zawartości Se w glebach. Natomiast pod względem genetycznym, środowiskowym, stylu życia oraz podaży jodu, populacja z tego obszaru tworzy grupę homogeniczną. Mediana stężenia Se w surowicy krwi wśród mieszkańców terenów bogatych w Se była równa 103,6 $\mu \mathrm{g} / \mathrm{L}$, a z terenów ubogich $w$ ten mikroelement $57,4 \mu \mathrm{g} / \mathrm{L}$. Na podstawie przeprowadzonych analiz stwierdzono, iż stężenie Se w surowicy krwi poniżej $70 \mu \mathrm{g} / \mathrm{L}$ wiązało się ze zwiększonym ryzykiem wystąpienia AZT o około: 1,7 (dla pierwszego kwantylu stężenia Se, tj. <47,0 $\mu \mathrm{g}$ Se/L) oraz 1,3 (dla drugiego kwantylu stężenia Se, tj. 47,0-68,9 $\mu \mathrm{g}$ Se/L) w porównaniu z ryzykiem ustalonym dla trzeciego kwantylu (69,0-90,9 $\mu \mathrm{g}$ Se/L) [7]. Warto zaznaczyć, iż tarczyca w porównaniu z innymi narządami odznacza się stosunkowo wysokim stężeniem Se, również w warunkach jego niedoboru [8, 9]. Mimo to, w warunkach zmniejszonej podaży Se, poziom ekspresji selenobiałek (głównych mediatorów biochemicznej aktywności Se) może być niewystarczający do skutecznej ochrony tkanki tarczycowej przed procesem autoimmunizacji lub jej uszkodzeniem [10].

Przegląd literatury podzielono na dwie części: w pierwszej skupiono się na pracach, w których zmiana stężenia przeciwciał anty-TPO była główną miarą oceny skuteczności suplementacji Se diety pacjentów z AZT. Natomiast w części drugiej ewaluacja immunoregulacyjnego działania Se w przebiegu choroby Hashimoto została rozpatrzona $\mathrm{w}$ odniesieniu do szerszego zakresu parametrów biochemicznych i immunologicznych. W artykule uwzględniono badania przeprowadzone w populacji europejskiej, w których suplementacja Se była stosowana sama lub $\mathrm{w}$ połączeniu $\mathrm{z} \mathrm{L}-\mathrm{T}_{4}$. W przygotowaniu przeglądu literatury korzystano z baz naukowych, takich jak: PubMed/ MEDLINE, Embase oraz Google Scholar.

\section{Selen w chorobie Hashimoto a zmiany stężeń autoprzeciwciał przeciwtarczycowych}

Dotąd przeprowadzono wiele niezależnych badań dotyczących wpływu Se na przebieg AZT, w których monitorowanie zmiany stężeń autoprzeciwciał przeciwtarczycowych anty-TPO było głównym celem. Stężenie przeciwciał anty-TPO ma wpływ na intensywność nacieków limfocytarnych w gruczole tarczowym i stopień uszkodzenia tego gruczołu, dlatego zmniejszenie wartości tego parametru pod wpływem Se może się przyczynić do skuteczniejszego leczenia pacjentów z chorobą Hashimoto. W tabeli 1 zestawiono wyniki badań, w których oceniano wpływ suplementacji Se diety pacjentów z AZT na stężenie przeciwciał anty-TPO oraz parametrów określających funkcje tarczycy.

Gärtner i wsp. [11] wykonali jedno z pierwszych takich badań w populacji niemieckiej. Warto zaznaczyć, że na terenie Niemiec występuje łagodny niedobór jodu i Se. W badaniach trwających 3 miesiące uczestniczyła grupa 70 kobiet z AZT. Pacjentki w sposób losowy zostały przydzielone do dwóch grup - pierwszej otrzymującej Se - w postaci selenianu(IV) sodu, w dawce $200 \mu \mathrm{g}$ Se/dobę, i drugiej otrzymującej placebo. Ponadto, w celu utrzymania stężenia TSH w zakresie prawidłowym, u wszystkich uczestniczek stosowana była terapia $\mathrm{L}-\mathrm{T}_{4}$. Suplementacja diety Se wpłynęła na zmniejszenie średniego stężenia przeciwciał anty-TPO o 36,4\%. Wśród pacjentek, u których w największym stopniu odnotowano zmianę miana tych przeciwciał, poprawiła się również echogeniczność tarczycy. W przypadku parametrów tarczycowych: wolnej tyroksyny $\left(\mathrm{fT}_{4}\right)$, trijodotyroniny $\left(\mathrm{fT}_{3}\right)$ oraz TSH, jak również anty-TG, zwiększona podaż Se nie wpłynęła znamiennie na ich wartości [11]. Kontynuacja suplementacji przez kolejne 6 miesięcy doprowadziła do dalszego znamiennego obniżania stężenia anty-TPO. U pacjentek, u których Se zastąpiono placebo, odnotowano statystycznie istotny wzrost stężenia anty-TPO [12].

Podobne badania zostały przeprowadzone także w populacji greckiej, w grupie 65 pacjentów - w większości kobiet - z AZT z subkliniczną niedoczynnością tarczycy. Podawanie Se w postaci selenometioniny, w dawce 200 ug Se/dobę, przez 6 miesięcy, w połączeniu z L-T , również wpłynęło na obniżenie miana przeciwciał anty-TPO 


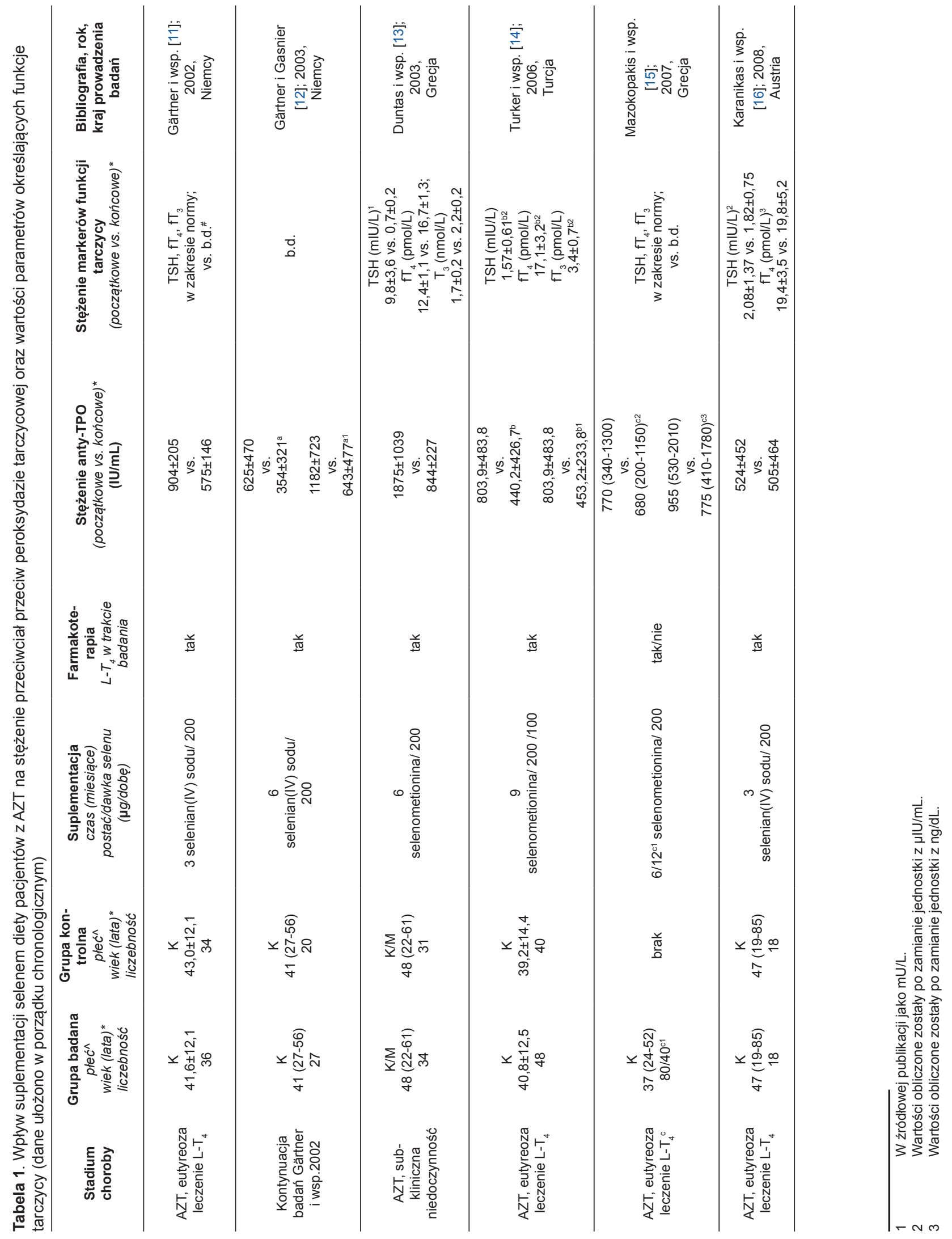




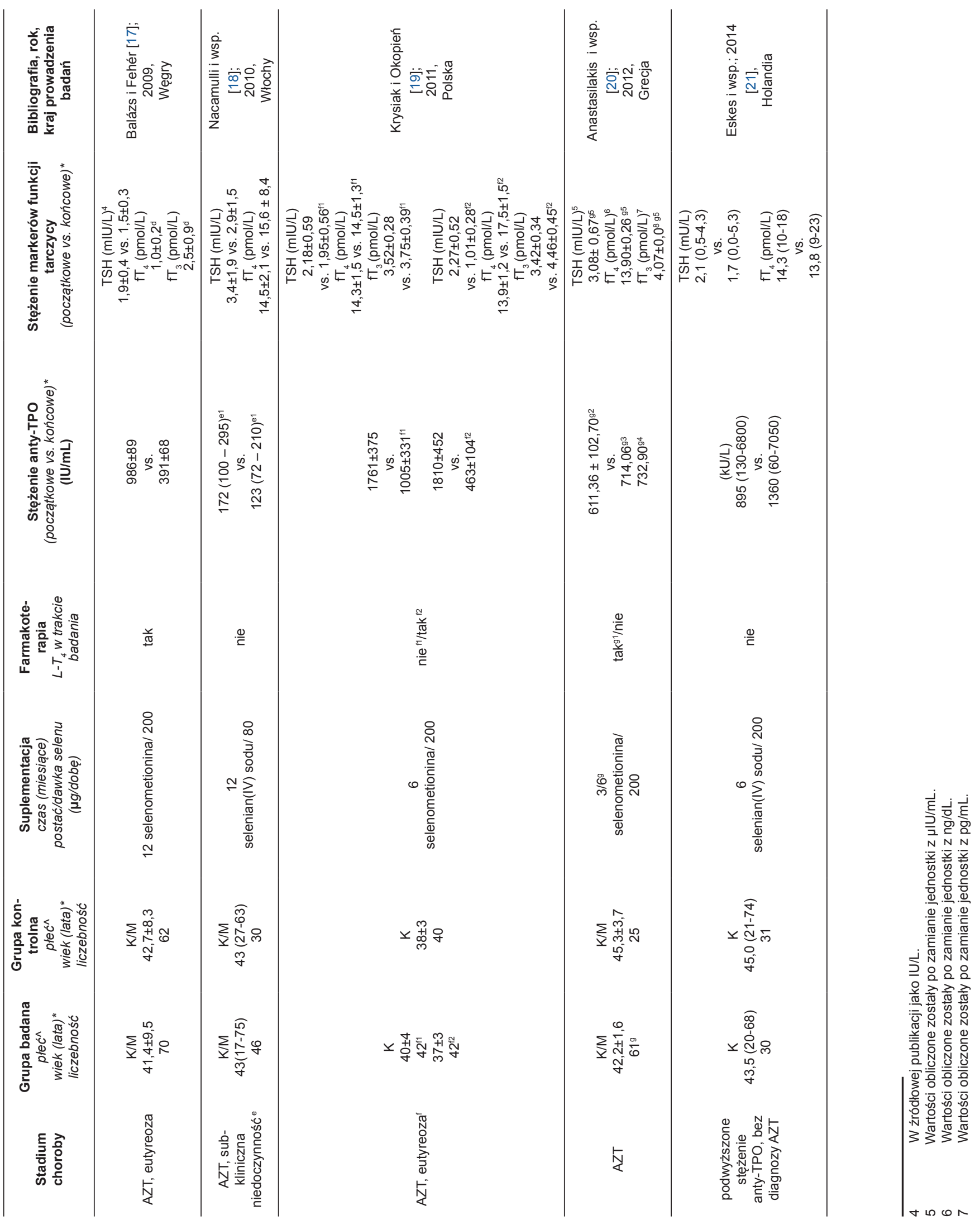




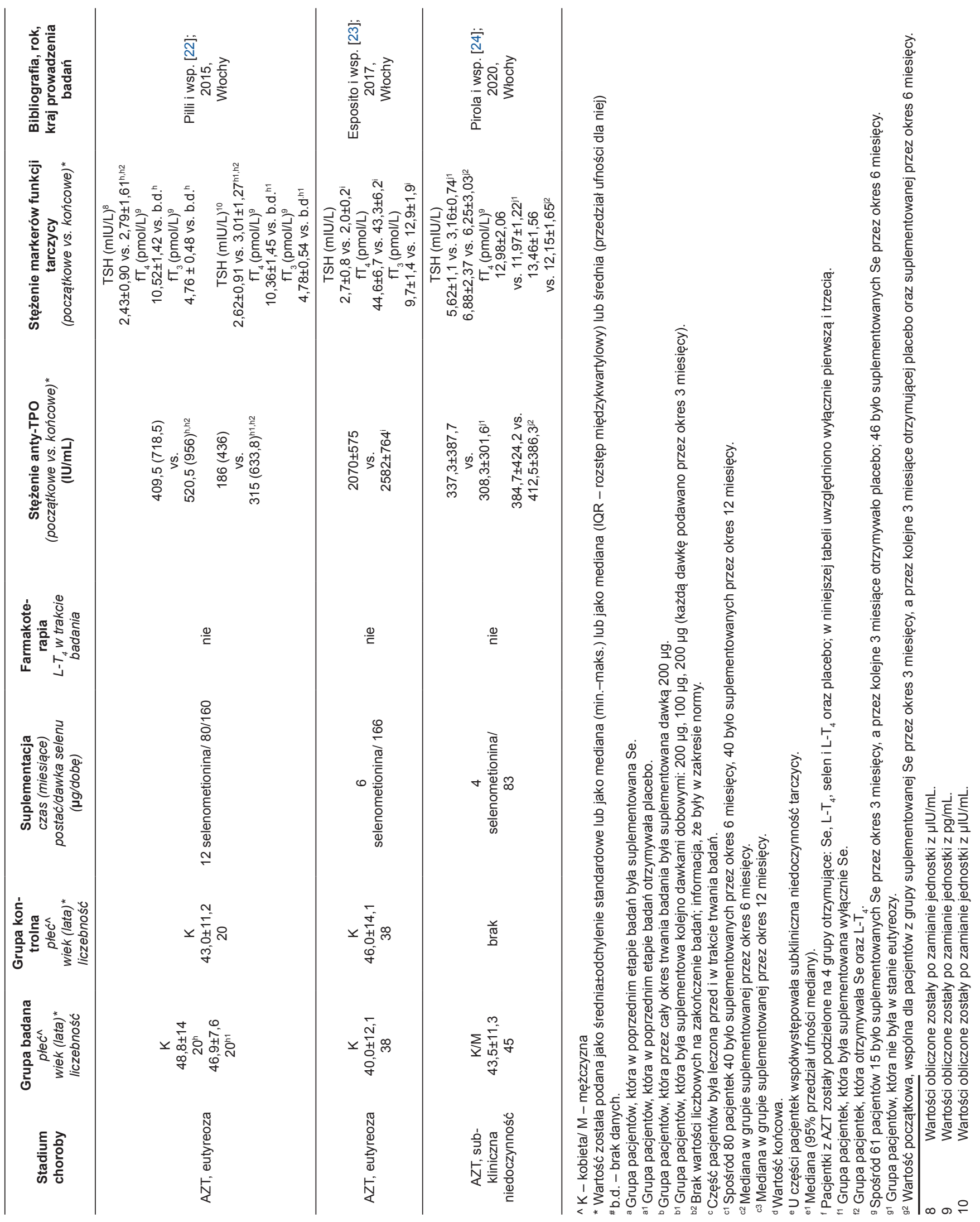




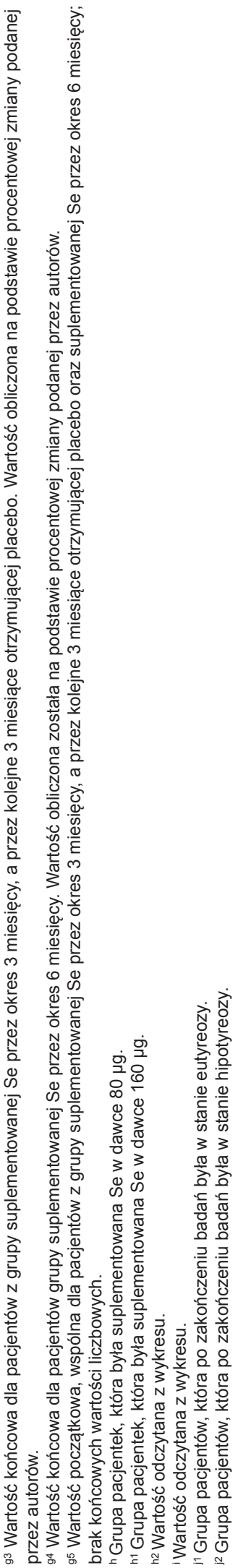

odpowiednio o 46 i 55,5\% względem wartości początkowej po upływie odpowiednio - 3 i 6 miesięcy. W tym samym czasie odnotowane zmniejszenie stężenia anty-TPO w grupie placebo było na poziomie 21 i $27 \%$. Uczestnicy badań pochodzili z regionu o wystarczającej podaży Se, a jego wyjściowe stężenie w surowicy krwi nie różniło się między grupami. Zatem znaczące zmniejszenie stężenia antyTPO w grupie badanej, szczególnie widoczne po upływie 3 miesięcy spożywania suplementu Se, może sugerować wcześniejsze obniżenie wewnątrztarczycowej zawartości tego pierwiastka u tych pacjentów, a tym samym wskazuje na osłabienie układu antyoksydacyjnego w warunkach długotrwałego stanu zapalnego. Nie zaobserwowano wpływu Se na zmianę stężenia anty-TG oraz wartości parametrów związanych z funkcją tarczycy $\left(\mathrm{fT}_{4}, \mathrm{~T}_{3}\right.$ oraz $\left.\mathrm{TSH}\right)$ [13].

Turker i wsp. [14] również dowiedli wynikami swoich badań (przeprowadzonych w Turcji, w grupie 88 pacjentek z AZT w stanie eutyreozy), iż Se skutecznie zmniejsza miano antyTPO bez wyraźnego oddziaływania na parametry tarczycowe. Spożywanie Se w postaci selenometioniny, w dawce $200 \mu \mathrm{g}$ Se/dobę, w połączeniu z L-T 4 przez 6 miesięcy miało wpływ na znamienne obniżenie wartości tego parametru prawie o $50 \%$. Kontynuacja powyższego schematu leczenia przez następne 3 miesiące w sposób znikomy zmodyfikowała wytwarzanie tych przeciwciał. W grupie pacjentek, w której po 3 miesiącach od rozpoczęcia badań zmniejszono dawkę Se z 200 do $100 \mu \mathrm{g} /$ dobę na okres kolejnych 3 miesięcy, miano anty-TPO wzrosło statystycznie istotnie o $38,1 \%$. Była to jednak zmiana odwracalna w warunkach ponownego zwiększenia dawki do $200 \mu \mathrm{g}$ Se/dobę.

Istotne jest to, iż w wyżej przytoczonych wynikach badań wpływ Se na zmniejszenie procesu autoimmunizacji w AZT, za pośrednictwem regulowania miana anty-TPO, był widoczny zarówno u pacjentów z jego łagodnym niedoborem [11, 14], jak również z prawidłowymi zasobami tego pierwiastka [13]. Ponadto należy podkreślić, iż zmiany wartości stężeń anty-TPO były szczególnie widoczne w początkowych etapach suplementacji diety Se, zwłaszcza przy względnie wysokim stężeniu anty-TPO [11, 14].

W innym badaniu, przeprowadzonym na terenie Krety w grupie 80 pacjentek (dotyczy pierwszych 6 miesięcy trwania badań), porazkolejny potwierdzono wpływ Se nazmniejszanie stężenia przeciwciał anty-TPO, stosując selenometioninę w dawce $200 \mu \mathrm{g}$ Se/dobę, jednak obserwacje dotyczące dynamiki zmian stężenia anty-TPO w ciągu 12 miesięcy były nieco odmienne względem wcześniej przytoczonych prac. W pierwszym półroczu odnotowano jego zmniejszenie o 5,6 i 9,9\% (w stosunku do wartości początkowej) po upływie odpowiednio 3 i 6 miesięcy, podczas gdy na zakończenie drugiego półrocza suplementacji o kolejne 8\% (w tej części badań uczestniczyło 40 pacjentek). Potencjalnym czynnikiem mogącym wpływać na różnice w skali oddziaływania Se 
na wytwarzanie anty-TPO jest jego wyjściowe stężenie w tkance tarczycowej. Natomiast na wewnątrztarczycową zawartość tego mikroelementu mają wpływ intensywność stresu oksydacyjnego i codzienna dieta, mogące się różnić w zależności od pochodzenia badanej grupy pacjentów. Odmienny stopień wysycenia tarczycy Se może również wyjaśniać, dlaczego u pacjentek, u których suplementacja była stosowana tylko przez pół roku, w ciągu kolejnych 6 miesięcy stężenie anty-TPO zwiększyło się o 4,8\% [15].

W rocznym badaniu, w którym uczestniczyło 132 pacjentów z Węgier ( $w$ większości kobiety), poza istotnym zmniejszeniem stężenia anty-TPO oraz anty-TG $w$ grupie stosującej Se (w postaci selenometioniny, w dawce $200 \mu \mathrm{g}$ Se/dobę) w połączeniu z L-T , stwierdzono także znamienne zwiększenie stosunku $\mathrm{fT}_{3}$ do $\mathrm{fT}_{4} \mathrm{w}$ porównaniu do grupy kontrolnej. Zaobserwowano również ujemną korelację między stężeniem anty-TPO a całkowitą zdolnością antyoksydacyjną osocza [17].

Nacamulli i wsp. [18], stosując nieorganiczną postać Se - selenian(IV) sodu, w dawce równiej $80 \mu \mathrm{g}$ Se/dobę przez 12 miesięcy, również odnotowali istotną zmianę stężenia autoprzeciwciał przeciwtarczycowych w grupie 46 włoskich pacjentów (w większości kobiet) we wczesnych stadiach AZT. Zmniejszenie miana anty-TPO zaobserwowano już po 6 miesiącach od rozpoczęcia suplementacji, której kontynuacja przez następne pół roku pozwoliła na uzyskanie jeszcze lepszych wyników. W przypadku stężenia anty-TG istotne zmiany zostały odnotowane dopiero po upływie 12 miesięcy. Podobnie stopień obniżenia echogeniczności tarczycy - świadczący o naciekach limfocytarnych w jej obrębie został ograniczony dopiero po zakończeniu badań. Zatem można przypuszczać, iż stosowanie Se także w niższych dawkach, przez dłuższy okres, może być wystarczające do spowolnienia rozwoju AZT w jego początkowych stadiach. Wpływ Se na wartość TSH oraz $\mathrm{fT}_{4}$ nie został odnotowany w tych badaniach na poziomie istotnym statystycznie.

W rocznym badaniu przeprowadzonym na terenie Macedonii również odnotowano wpływ Se na zmniejszanie miana anty-TPO. Grupie 500 pacjentów w różnych fazach rozwoju choroby Hashimoto (tj. w stanie eutyreozy, ze wspótistniejącą subkliniczną lub jawną hipotyreozą) podawano Se (autorzy nie uściślili, w jakiej postaci) w dawce 50-150 $\mu \mathrm{g}$ Se/dobę, w zależności od wyjściowego stężenia tego parametru. W grupie 178 pacjentów z mianem anty-TPO $>1000 \mathrm{IU} / \mathrm{mL}$ zastosowanie $150 \mu \mathrm{g}$ Se/dobę wpłynęło na zmniejszenie tego miana do wartości $500-1000 \mathrm{IU} / \mathrm{mL}$ oraz $<500 \mathrm{IU} / \mathrm{mL}$ odpowiednio u 68 oraz 43 osób. W grupie 150 pacjentów z mianem autoprzeciwciał w zakresie 500-1000 IU $/ \mathrm{mL}$ podawanie Se w dawce $100 \mu \mathrm{g}$ Se/dobę wpłynęło na zmniejszenie anty-TPO do wartości $<500 \mathrm{IU} / \mathrm{mL}$ u 83 osób. Wśród 172 uczestników badań z najniższym stężeniem tych autoprzeciwciał (tj. 50-500 IU/mL), którzy otrzymywali $50 \mu \mathrm{g} \mathrm{Se} / \mathrm{dobę,}$ zmniejszenie miana anty-TPO do zakresu prawidłowego (tj. $<35 \mathrm{IU} / \mathrm{mL}$ ) odnotowano u 91 pacjentów [25].

Natomiast Anastasilakis i wsp. [20] uzyskali wyniki, które nie wykazały żadnego dobroczynnego wpływu Se na przebieg AZT podczas 6-miesięcznej suplementacji diety 61 pacjentów ( $w$ większości kobiet) selenometioniną $w$ dawce $200 \mu \mathrm{g}$ Se/dobę, ponieważ nie stwierdzono istotnych zmian żadnego $z$ analizowanych parametrów, takich jak: stężenie anty-TPO, anty-TG, TSH, $\mathrm{fT}_{4}$ czy $\mathrm{fT}_{3}$ czy też stopień zaawansowania nacieków limfocytarnych w obrębie tkanki tarczycowej. Badania te przeprowadzono w populacji greckiej.

Do podobnych wniosków doszli Eskes i wsp. [21] w badaniach holenderskich, $\mathrm{z}$ udziałem 61 kobiet z przeciwciałami anty-TPO obecnymi we krwi. Pacjentki pozostawały w stanie eutyreozy i nie wymagały leczenia L-T ${ }_{4}$. Se był podawany w postaci selenianu(IV) sodu w dawce $200 \mu \mathrm{g}$ Se/dobę w grupie 30 kobiet przez 6 miesięcy. Mimo że po upływie 3 miesięcy (od rozpoczęcia suplementacji) stężenie Se oraz selenobiałka P (SELENOP) w surowicy krwi pacjentek osiągnęło stan plateau, nie zaobserwowano istotnych zmian stężenia anty-TPO, jak również $\mathrm{TSH} \mathrm{fT}_{4}$ na żadnym $z$ etapów trwania badania. Autorzy przytoczonych badań, próbując zinterpretować uzyskane wyniki, zwrócili uwagę na podaż jodu. Niewykluczone, że niedobór jodu, powodujący zwiększone wytwarzanie $\mathrm{H}_{2} \mathrm{O}_{2}$, sprzyja powstawaniu stresu oksydacyjnego $w$ tkance tarczycowej. Natomiast w warunkach niedoboru Se, z powodu zmniejszonej syntezy selenobiałek, układ antyoksydacyjny ulega osłabieniu, co dodatkowo intensyfikuje natężenie stresu oksydacyjnego [26]. Zatem oddziaływanie suplementacji diety Se na wytwarzanie anty-TPO jest skuteczniejsze wśród pacjentów pochodzących $z$ terenów niedoborowych w jod (ale bez jawnego deficytu jodu jak np. w Afryce) [21], podczas gdy w populacji holenderskiej obserwowane jest wystarczające jego spożycie [27]. Przypuszczenie to wymaga jednak weryfikacji.

Potencjalną przyczyną rozbieżności przytoczonych wyników badań są również polimorfizmy pojedynczych nukleotydów (SNP) występujące w genach kodujących poszczególne selenobiałka. Niewykluczone, że stopień wykorzystania zasobów selenowych w organizmie człowieka jest regulowany przez obecność takich polimorfizmów [28]. Jablonska i wsp. [29] zaobserwowali, iż zmiana aktywności peroksydazy glutationowej 1 (GPX1) w erytrocytach, w zależności od stężenia Se w surowicy krwi, była uwarunkowana SNP genu kodującego ten enzym. Jednak wśród pacjentów z AZT z różnymi SNP dla GPX1 nie odnotowano różnic w obniżaniu miana anty-TPO w odpowiedzi na 3-miesięczną suplementację diety Se [30]. Natomiast w przypadku selenobiałka S (SELENOS), 
które prawdopodobnie bierze udział w procesie niszczenia białek o nieprawidłowo ukształtowanych strukturach, a także odpowiada $\mathrm{w}$ jakimś stopniu za przeciwzapalne właściwości Se, obserwacje w odniesieniu do SNP są bardziej czytelne. Zaburzenie syntezy SELENOS (w wyniku SNP w obrębie promotora genu kodującego to białko G105A) sprzyja wytwarzaniu cytokin prozapalnych, takich jak IL-1 $\beta$ i czynnik martwicy nowotworu- $\alpha$ (TNF- $\alpha$ ) [31]. IL-1 $\beta$ uwrażliwia tyreocyty na apoptozę [32, 33, 34], a TNF- $\alpha$ wzmacnia ukierunkowaną migrację limfocytów $T_{1}$ do tkanki tarczycowej, co stanowi istotny czynnik uszkadzający tarczycę [35]. Santos i wsp. [36] zaobserwowali także wpływ tego zjawiska na zwiększenie ryzyka wystąpienia AZT.

AZT należy do jednego z najpowszechniej występujących typów zapalenia gruczołu tarczowego w grupie dzieci i młodzieży [37]. Jest również główną przyczyną zaburzeń funkcji tarczycy w regionach prawidłowego nasycenia jodem [38]. Dotychczas ocena wpływu suplementacji diety Se na przebieg AZT w tej grupie wiekowej została przeprowadzona tylko $\mathrm{w}$ jednym badaniu klinicznym wykonanym na terenie Niemiec [39]. Stosowanie Se (w postaci selenianu(IV)

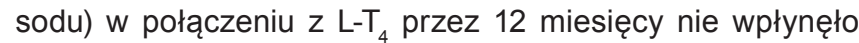
znamiennie na zmniejszenie wytwarzania anty-TPO, niezależnie od dawki, w jakiej mikroelement ten był podawany (tj. 100 lub $200 \mu \mathrm{g}$ Se/dobę), w porównaniu do wyników, jakie zostały odnotowane $w$ monoterapii $L-T_{4}$. Warto jednak zwrócić uwagę, iż w grupie pacjentów suplementowanych wyższą dawką Se wyjściowa wartość tego parametru została zmniejszona o 40,5\% (wobec 22,5 i 21\% odpowiednio, w grupie z niższą dawką Se oraz z monoterapią L-T ), natomiast niewykluczone, że brak statystycznie istotnych różnic między poszczególnymi grupami wynikał z niewielkiej ich liczebności (tj. 18, 13 oraz 18 pacjentów - przeważnie dziewczęta-odpowiednio w grupie: otrzymującej Se w dawce 200, $100 \mu \mathrm{g} /$ dobę oraz kontrolnej). $\mathrm{W}$ przypadku anty-TG uzyskano odmienne wyniki. W grupie otrzymującej wyższą dawkę Se wraz z L-T miano przeciwciał anty-TG uległo statystycznie istotnemu obniżeniu w porównaniu do wartości początkowej, podobną obserwację odnotowano również w grupie leczonej wyłącznie L-T ${ }_{4}$ [39]. Być może oznaczenie u pacjentów Se i/lub wybranych selenobiałek pozwoliłoby na lepszą ocenę wyników stosowania łączonej terapii na przebieg AZT, tym bardziej, że do badań rekrutowane były osoby z nowo zdiagnozowaną chorobą.

Nourbakhsh i wsp. [40] nie wykluczają, iż właśnie stadium rozwoju choroby, oprócz podaży Se w danym regionie, może mieć istotny wpływ na efekt suplementacji diety Se. $W$ badaniach nie odnotowali zróżnicowania stężeń Se, SELENOP, jak też aktywności GPX3 w surowicy krwi między grupą dzieci i młodzieży z rozpoznanym już wcześniej AZT (wśród których terapię L-T ${ }_{4}$ stosowano od co najmniej 2 lat) a grupą kontrolną utworzoną z osób zdrowych.
Obecność przeciwciał anty-TPO w czasie ciąży ma istotne znaczenie $z$ punktu widzenia częstości wystąpienia poporodowego zapalenia tarczycy (PZT). Termin PZT obejmuje autoimmunologiczne schorzenie tego gruczołu, z wyłączeniem choroby Gravesa, powstałe de novo do 1. roku od porodu. Częstość występowania tego typu zapalenia szacowana jest na poziomie około $5,4 \%$ ogólnej populacji kobiet. Należy jednak podkreślić, że PZT występuje nawet u 50\% kobiet, u których w pierwszym trymestrze ciąży obecne były przeciwciała przeciwtarczycowe (antyTPO i/lub anty-TG) [41]. Obecność tych przeciwciał w czasie ciąży może zwiększać ryzyko poronienia bądź też przedwczesnego porodu [42, 43]. Mimo wielu przesłanek wskazujących na Se jako czynnik regulujący miano autoprzeciwciał przeciwtarczycowych w ogólnej populacji kobiet, aktualny stan wiedzy na ten temat u kobiet ciężarnych jest niewystarczający. W jednym z nielicznych badań wykazano, iż suplementacja Se diety kobiet (pozostających w stanie eutyreozy) $z$ obecnymi przeciwciałami anty-TPO w trakcie ciąży i w okresie pierwszego roku po porodzie wyraźnie wpłynęła na zmniejszenie ryzyka rozwoju PZT. Stężenie anty-TPO uległo znamiennemu obniżeniu, a ponadto echogeniczność tkanki tarczycowej poprawiła się w porównaniu do kobiet, które otrzymywały placebo. Se był podawany w postaci selenometioniny, w dawce $200 \mu \mathrm{g} \mathrm{Se/}$ dobę przez 18 miesięcy, począwszy od II trymestru ciąży w grupie 77 kobiet. Badania przeprowadzono we Włoszech [44]. Mao i wsp. [45] nie zaobserwowali natomiast różnic w stężeniu anty-TPO wśród pacjentek z Anglii, które między 12. a 35. tygodniem ciąży były suplementowane Se (w dawce $60 \mu \mathrm{g}$ Se/dobę w postaci selenowanych drożdży) a grupą otrzymującą placebo. Należy jednak podkreślić istnienie zasadniczych różnic między przytoczonymi wynikami badań, dotyczących m.in.: dawki Se (200 vs. $60 \mu \mathrm{g}$ Se/dobę), wyjściowego stężenia przeciwciał anty-TPO (mediana: 600 vs. $110 \mathrm{IU} / \mathrm{mL}$ ), liczebności uczestniczek badań z obecnymi przeciwciałami (151 vs. 25) oraz - przypuszczalnie podaży jodu [45]. W badaniach Negro i wsp. [44] pacjentki były zobowiązane do stosowania soli jodowanej, ale nie wykonano analiz pozwalających określić stopień wysycenia jodem, podczas gdy uczestniczki badań Mao i wsp. [45] miały stany niedoboru jodu, od lekkiego po umiarkowany, co wykazano na podstawie oznaczeń jodu w moczu.

\section{Selen w chorobie Hashimoto a zmiany parametrów biochemicznych i immunologicznych}

W badaniach Karanikasa i wsp. [16] grupa 18 pacjentek z AZT w Austrii była suplementowana nieorganiczną postacią Se, tj. selenianem(IV) sodu w dawce $200 \mu \mathrm{g}$ Se/dobę, przez 3 miesiące. Ponadto, w celu utrzymania wartości TSH wzakresie 
prawidłowym, jednocześnie stosowana była L-T. Autorzy badań nie odnotowali wyraźnych zmian w wytwarzaniu cytokin (takich jak: IL-2, -4, -10, -13, interferon- $\mathrm{Y}$ (IFN- $\mathrm{y}$ ) oraz TNF- $\alpha$ ), wydzielanych przez komórki limfocytów $\mathrm{T} \mathrm{CD4} 4^{+} \mathrm{i} C D 8^{+}$we krwi obwodowej pacjentów w warunkach zwiększonej podaży Se. Stężenie anty-TPO również nie uległo obniżeniu. Jednak należy podkreślić, iż podczas rekrutacji nie obowiązywało obostrzenie względem minimalnego stężenia tych przeciwciał. Początkowa średnia wartość dla tego parametru była równa $524 \pm 452 \mathrm{IU} / \mathrm{mL}$ i została uznana przez autorów za umiarkowanie wysoką. Warto także zwrócić uwagę na dużą wartość odchylenia standardowego tego miana $w$ badanej grupie. Autorzy badań przypuszczają, że dopiero przy wzmożonym, wewnątrztarczycowym stanie zapalnym, prowadzącym do intensywniejszego wytwarzania anty-TPO, mogą się pojawić także zmiany w wytwarzaniu cytokin [16]. Tym bardziej że u pacjentów z AZT, u których miano anty-TPO było większe niż $1000 \mathrm{IU} / \mathrm{mL}$, zaobserwowano znamiennie wyższe stężenie IFN-y oraz TNF- $\alpha$ w porównaniu do osób zdrowych [46].

W 2011 r. opublikowano wyniki badań Krysiaka i Okopienia [19], przeprowadzonych w polskiej populacji, których głównym celem była ocena przeciwzapalnych właściwości L-T $\mathrm{T}_{4}$ i selenometioniny stosowanych osobno lub łącznie w warunkach nowo zdiagnozowanej, wcześniej nieleczonej choroby Hashimoto. Dawka L-T 4 była ustalana indywidualnie na podstawie wartości $\mathrm{TSH}$, natomiast Se podawano $\mathrm{w}$ dawce $200 \mu \mathrm{g}$ Se/dobę. Badanie trwało 6 miesięcy i zostało ukończone przez grupę 165 uczestniczek. Zarówno ${\mathrm{L}-\mathrm{T}_{4}}_{4}$ jak i Se hamowały proces zapalny, ale za pośrednictwem odmiennych efektorów. L-T ${ }_{4}$ zmniejszała wydzielanie cytokin prozapalnych, takich jak: TNF- $\alpha, \mathrm{IL}-1 \beta$, IL-6 i białko chemotaktyczne monocytów 1 (MCP-1, monocyte chemotactic protein-1), regulując aktywność wydzielniczą monocytów, podczas gdy Se hamował sekrecję TNF- $\alpha$, IL-2 i IFN-y oddziałując na limfocyty. Warto podkreślić, że efekty były najlepiej widoczne podczas stosowania $\mathrm{L}_{4} \mathrm{~T}$ w połączeniu z Se. Mechanizmy leżące u podstaw uzyskanych wyników nie są znane. Krysiak i Okopień [19], w oparciu o wyniki badań przeprowadzonych w populacji węgierskiej [47], w których odnotowano statystycznie wyższe stężenie $\mathrm{T}_{3} \mathrm{w}$ monocytach aniżeli w limfocytach, wskazali na różnice w pobieraniu oraz metabolizowaniu L-T $\mathrm{T}_{4}$ między tymi rodzajami komórek jako jedną z potencjalnych przyczyn odmienności obserwowanych wyników. Niewątpliwie badania na poziomie molekularnym są niezbędne, aby poznać przyczynę odmiennego oddziaływania badanych związków na poszczególne grupy komórek układu immunologicznego. Innym dowodem wskazującym na przeciwzapalny profil działania $\mathrm{L}_{4}$ i Se, jaki w tych badaniach udało się zaobserwować, było znamienne obniżenie stężenia białka C-reaktywnego (CRP) - markera ogólnoustrojowego stanu zapalnego. Co istotne, w odpowiedzi na L-T $T_{4}$ i/lub Se znamiennemu obniżeniu uległo również miano anty-TPO. Trzeba jednak zaznaczyć, że obserwacje zostały przeprowadzone w grupie pacjentek w stanie eutyreozy $\mathrm{i}$ nie powinny być ekstrapolowane na warunki zaburzonego wytwarzania $\mathrm{T}_{4} \mathrm{i}_{3} \mathrm{~T}_{3} \mathrm{w}$ wyniku niedoczynności tarczycy [19].

Inne badania, w których ocena immunoregulacyjnych właściwości Se była rozpatrywana również w szerszym zakresie parametrów biochemicznych, zostały przeprowadzone w populacji włoskiej, w grupie 60 kobiet z AZT. Wpływ Se na funkcje układu immunologicznego był analizowany za pomocą zmiany stężeń chemokin, takich jak: CXCL-9, CXCL-10, CXCL-11 oraz cytokin IFN-y i TNF-a [22]. Jedną z głównych funkcji chemokin jest rekrutowanie różnych subpopulacji leukocytów do miejsc objętych stanem zapalnym. Wymienione wyżej chemokiny (CXCL-9, 10, 11) są związane z odpowiedzią immunologiczną zależną od komórek Th ${ }_{1}$ [48], których nadmierna aktywacja występuje w przebiegu choroby Hashimoto. Podwyższone stężenie tych CXCL wśród pacjentów z nowo zdiagnozowaną AZT w porównaniu do osób zdrowych sugeruje ich rolę $\mathrm{w}$ patogenezie tego schorzenia [49, 50, 51, 52]. Przypuszczalnie tyreocyty $w$ obecności IFN- $\gamma$ i TNF- $\alpha$ (cytokin prozapalnych wydzielanych przez limfocyty $T h_{1}$ ) uwalniają chemokiny CXCL-9, CXCL-10, CXCL-11, a to sprzyja tworzeniu się skupisk tych limfocytów w komórkach tarczycy [48]. Zatem próba oceny wpływu Se na ewentualne zmiany stężeń wspomnianych wyżej molekuł była uzasadniona. Do badań Pilli i wsp. [22] rekrutowano wyłącznie pacjentki w stanie eutyreozy, niewymagające stosowania terapii $\mathrm{L}-\mathrm{T}_{4}$. Uczestniczki w sposób losowy zostały przyporządkowane do 3 grup otrzymujących odpowiednio: placebo, Se (w postaci selenometioniny) w dawce $80 \mu \mathrm{g}$ Se/dobę oraz Se (w tej samej postaci) w dawce $160 \mu \mathrm{g}$ Se/dobę. Badanie trwało 12 miesięcy. Suplementacja diety Se, niezależnie od dawki, wpłynęła statystycznie istotnie na zmniejszenie stężenia chemokin CXCL-9 i 10. Natomiast w przypadku chemokiny CXCL-11 oraz cytokin IFN- $y$ i TNF- $\alpha$ takie zmiany zostały odnotowane $\mathrm{w} 6$. miesiącu od rozpoczęcia badań. Po upływie kolejnych 6 miesięcy (tj. na zakończenie badań), wartości tych parametrów były ponownie zbliżone do wartości początkowych, co może dowodzić złożoności mechanizmów leżących u podstaw immunoregulacyjnego działania Se w przebiegu AZT. W przypadku przeciwciał anty-TPO suplementacja diety Se, niezależnie od dawki, nie wpłynęła na istotną statystycznie zmianę ich stężenia. Biorąc jednak pod uwagę to, że w grupie placebo w 6. i 9. miesiącu odnotowano wzrost mediany stężenia anty-TPO, odpowiednio o około 45 i $27 \%$ względem wartości wyjściowej, a następnie stężenie to utrzymywało się na podobnym poziomie, warto zwrócić uwagę na potencjalnie ochronne działanie Se w rozwoju choroby [22]. 
Ocena wpływu suplementacji diety Se na wytwarzanie chemokin CXCL-9, CXCL-10 oraz CXCL-11 wśród włoskich pacjentów z AZT była również przedmiotem badań Pirola i wsp. [24]. Podawanie Se w postaci selenometioniny, w dawce $83 \mu \mathrm{g}$ Se/dobę przez 4 miesiące, wpłynęło na znamienne obniżenie stężenia tylko CXCL-9. Autorzy przytoczonych badań także nie odnotowali statystycznie istotnych zmian stężenia przeciwciał anty-TPO.

Podobnie wyniki innych badań, przeprowadzonych również we włoskiej populacji, nie potwierdziły udziału Se w regulowaniu stężenia chemokiny CXCL-10 jak również anty-TPO. W tym przypadku dieta 38 pacjentek z AZT $w$ stanie eutyreozy była suplementowana Se w dawce $166 \mu \mathrm{g}$ Se/dobę (w postaci selenometioniny) przez 6 miesięcy [23].

$\mathrm{Na}$ podstawie dostępnej literatury, niezbędna jest kontynuacja tego typu badań, w celu dokładniejszego poznania wpływu Se na funkcje układu immunologicznego w przebiegu AZT. mogą być pomocne w ewentualnym formułowaniu nowych wytycznych dotyczących leczenia i suplementacji pacjentów.

\section{Wykaz skrótów}

anty-TG - autoprzeciwciała przeciwtarczycowe przeciw tyreoglobulinie; anty-TPO - autoprzeciwciała przeciwtarczycowe przeciw peroksydazie tarczycowej; AZT - autoimmunologiczne zapalenie tarczycy (synonim: choroba Hashimoto); CXCL10 - chemokina 10 (synonim: IP-10 - białko indukowane przez interferon); $\mathbf{f T}_{3}$ - wolna frakcja trijodotyroniny; $\mathbf{f T}_{4}$ - wolna frakcja tyroksyny; GPX - peroksydaza glutationowa; L-T - L-tyroksyna; Se selen; SELENOP - selenobiałko P; SNP - polimorfizm pojedynczego nukleotydu; $\mathrm{T}_{3}$ - trijodotyronina; $\mathbf{T}_{4}-$ tyroksyna; TG - tyreoglobulina; TPO - peroksydaza tarczycowa; TSH tyreotropina (synonim: hormon tyreotropowy).

\section{Konflikt interesów}

Podsumowując, można stwierdzić, iż w wyżej cytowanych pracach brakuje spójności wyników. Ponadto częste ograniczanie monitorowania wpływu Se na przebieg choroby do oznaczania tylko miana autoprzeciwciał nie jest w pełni pomocne w zrozumieniu mechanizmów, za pomocą których Se może uczestniczyć w regulowaniu rozwoju procesu autoimmunologicznego w chorobie Hashimoto. W dotychczasowych badaniach często brakowało szczegółowej oceny zasobów selenowych organizmu, w której uwzględnione zostałyby selenobiałka uczestniczące w dystrybucji Se, a także we wzmacnianiu potencjału antyoksydacyjnego.

Pomijany był także aspekt dokładnego ustalenia podaży jodu wśród uczestników. Zamiast tego autorzy powoływali się na ogólną populacyjną tendencję spożycia tego pierwiastka. Ponadto, wiedząc, że w wyjaśnianiu zaburzeń immunologicznych w patogenezie AZT zwraca się szczególną uwagę na zwiększoną aktywność limfocytów Th, $[53,54]$ oraz $\operatorname{Th}_{17}[55,56,57]$, ewaluacja zmian w wytwarzaniu cytokin przez te komórki również wydaje się niezbędna.

W świetle dotychczas przeprowadzonych badań rola Se w AZT nadal jest słabo poznanym zagadnieniem. Ponadto konkluzje pochodzące $z$ dwóch najnowszych metaanaliz (w których większość z uwzględnionych badań klinicznych była przeprowadzona w populacji europejskiej) wskazują na potrzebę kontynuowania badań oceniających wpływ suplementacji diety Se na przebieg choroby Hashimoto. Istotne, aby obejmowały one także inne niż anty-TPO/antyTG parametry kliniczne [58, 59]. Dopiero wyniki takich badań
Autorzy deklarują brak potencjalnych konfliktów interesów.

\section{Piśmiennictwo}

[1] Caturegli P., De Remigis A., Chuang K., Dembele M., Iwama A., Iwama S.: Hashimoto's thyroiditis: Celebrating the centennial through the lens of the Johns Hopkins Hospital surgical pathology records. Thyroid, 2013; 23: 142-150

[2] Hiromatsu Y., Satoh H., Amino N.: Hashimoto's thyroiditis: History and future outlook. Hormones, 2013; 12: 12-18

[3] Pearce E.N., Farwell A.P., Braverman L.E.: Thyroiditis. N. Engl. J. Med., 2003; 348: 2646-2655

[4] Bülow Pedersen I., Knudsen N., Carlé A., Schomburg L., Köhrle J., Jørgensen T., Rasmussen L.B., Ovesen L., Laurberg P.: Serum selenium is low in newly diagnosed Graves' disease: A populationbased study. Clin. Endocrinol., 2013; 79: 584-590

[5] Glattre E., Nygård J.F., Aaseth J.: Selenium and cancer prevention: Observations and complexity. J. Trace Elem. Med. Biol., 2012; 26: 168-169

[6] Rasmussen L.B., Schomburg L., Köhrle J., Pedersen I.B., Hollenbach B., Hög A., Ovesen L., Perrild H., Laurberg P.: Selenium status, thyroid volume, and multiple nodule formation in an area with mild iodine deficiency. Eur. J. Endocrinol., 2011; 164: 585-590

[7] Wu Q., Rayman M.P., Lv H., Schomburg L., Cui B., Gao C., Chen P., Zhuang G., Zhang Z., Peng X., Li H., Zhao Y., He X., Zeng G., Qin F., Hou P., Shi B.: Low population selenium status is associated with increased prevalence of thyroid disease. J. Clin. Endocrinol. Metab., 2015; 100: 4037-4047 
[8] Aaseth J., Frey H., Glattre E., Norheim G., Ringstad J., Thomassen Y.: Selenium concentrations in the human thyroid gland. Biol. Trace Elem. Res., 1990; 24: 147-152

[9] Bermano G., Nicol F., Dyer J.A., Sunde R.A., Beckett G.J., Arthur J.R., Hesketh J.E.: Tissue-specific regulation of selenoenzyme gene expression during selenium deficiency in rats. Biochem. J., 1995; 311: 425-430

[10] Schomburg L.: Selenium, selenoproteins and the thyroid gland: Interactions in health and disease. Nat. Rev. Endocrinol., 2011; 8: 160-171

[11] Gärtner R., Gasnier B.C., Dietrich J.W., Krebs B., Angstwurm M.W.: Selenium supplementation in patients with autoimmune thyroiditis decreases thyroid peroxidase antibodies concentrations. J. Clin. Endocrinol. Metab., 2002; 87: 1687-1691

[12] Gärtner R., Gasnier B.C.: Selenium in the treatment of autoimmune thyroiditis. Biofactors, 2003; 19: 165-170

[13] Duntas L.H., Mantzou E., Koutras D.A.: Effects of a six month treatment with selenomethionine in patients with autoimmune thyroiditis. Eur. J. Endocrinol., 2003; 148: 389-393

[14] Turker O., Kumanlioglu K., Karapolat I., Dogan I.: Selenium treatment in autoimmune thyroiditis: 9-month follow-up with variable doses. J. Endocrinol., 2006; 190: 151-156

[15] Mazokopakis E.E., Papadakis J.A., Papadomanolaki M.G., Batistakis A.G., Giannakopoulos T.G., Protopapadakis E.E., Ganotakis E.S.: Effects of 12 months treatment with L-selenomethionine on serum anti-TPO levels in patients with Hashimoto's thyroiditis. Thyroid, 2007; 17: 609-612

[16] Karanikas G., Schuetz M., Kontur S., Duan H., Kommata S., Schoen R., Antoni A., Kletter K., Dudczak R., Willheim M.: No immunological benefit of selenium in consecutive patients with autoimmune thyroiditis. Thyroid, 2008; 18: 7-12

[17] Balázs C., Fehér J.: The effect of selenium therapy on autoimmune thyroiditis. Clin. Exp. Med. J., 2009; 3: 269-277

[18] Nacamulli D., Mian C., Petricca D., Lazzarotto F., Barollo S., Pozza D., Masiero S., Faggian D., Plebani M., Girelli M.E., Mantero F., Betterle C.: Influence of physiological dietary selenium supplementation on the natural course of autoimmune thyroiditis. Clin. Endocrinol., 2010; 73: 535-539

[19] Krysiak R., Okopien B.: The effect of levothyroxine and selenomethionine on lymphocyte and monocyte cytokine release in women with Hashimoto's thyroiditis. J. Clin. Endocrinol. Metab., 2011; 96: 2206-2215

[20] Anastasilakis A.D., Toulis K.A., Nisianakis P., Goulis D.G., Kampas L., Valeri R.M., Oikonomou D., Tzellos T.G., Delaroudis S.: Selenomethionine treatment in patients with autoimmune thyroiditis: A prospective, quasi-randomised trial. Int. J. Clin. Pract., 2012; 66: 378-383

[21] Eskes S.A., Endert E., Fliers E., Birnie E., Hollenbach B., Schomburg L., Köhrle J., Wiersinga W.M.: Selenite supplementation in euthyroid subjects with thyroid peroxidase antibodies. Clin. Endocrinol., 2014; 80: 444-451
[22] Pilli T., Cantara S., Schomburg L., Cenci V., Cardinale S., Heid E.C., Kühn E.C., Cevenini G., Sestini F., Fioravanti C., D'Hauw G., Pacini F.: IFNY-inducible chemokines decrease upon selenomethionine supplementation in women with euthyroid autoimmune thyroiditis: Comparison between two doses of selenomethionine (80 or $160 \mu \mathrm{g}$ ) versus placebo. Eur. Thyroid J., 2015; 4: 226-233

[23] Esposito D., Rotondi M., Accardo G., Vallone G., Conzo G., Docimo G., Selvaggi F., Cappelli C., Chiovato L., Giugliano D., Pasquali D.: Influence of short-term selenium supplementation on the natural course of Hashimoto's thyroiditis: Clinical results of a blinded placebo-controlled randomized prospective trial. J. Endocrinol. Invest., 2017; 40: 83-89

[24] Pirola I., Rotondi M., Cristiano A., Maffezzoni F., Pasquali D., Marini F., Coperchini F., Paganelli M., Apostoli P., Chiovato L. i wsp.: Selenium supplementation in patients with subclinical hypothyroidism affected by autoimmune thyroiditis: Results of the SETI study. Endocrinol. Diabetes Nutr., 2020; 67: 28-35

[25] Manevska N., Stojanoski S., Makazlieva T.: Selenium treatment effect in auto-immune hashimoto thyroiditis in macedonian population. J. Endocrinol. Metab., 2019; 9: 22-28

[26] Krohn K., Maier J., Paschke R.: Mechanisms of disease: Hydrogen peroxide, DNA damage and mutagenesis in the development of thyroid tumors. Nat. Clin. Pract. Endocrinol. Metab., 2007; 3: 713-720

[27] Hendriksen M.A., van Raaij J.M., Geleijnse J.M., van den Hooven C.W., Ocké M.C., van der A D.: Monitoring salt and iodine intakes in Dutch adults between 2006 and 2010 using 24 h urinary sodium and iodine excretions. Public Health Nutr., 2014; 17: 1431-1438

[28] Karunasinghe N., Han D.Y., Zhu S., Yu J., Lange K., Duan H., Medhora R., Singh N., Kan J., Alzaher W., Chen B., Ko S., Triggs C.M., Ferguson L.R.: Serum selenium and single-nucleotide polymorphisms in genes for selenoproteins: Relationship to markers of oxidative stress in men from Auckland, New Zealand. Genes Nutr., 2012; 7: 179-190

[29] Jablonska E., Gromadzinska J., Reszka E., Wasowicz W., Sobala W., Szeszenia-Dabrowska N., Boffetta P.: Association between GPx1 Pro198Leu polymorphism, GPx1 activity and plasma selenium concentration in humans. Eur. J. Nutr., 2009; 48: 383-386

[30] de Farias C.R., Cardoso B.R., de Oliveira G.M., de Mello Guazzelli I.C., Catarino R.M., Chammas M.C., Cozzolino S.M., Knobel $M$.: A randomized-controlled, double-blind study of the impact of selenium supplementation on thyroid autoimmunity and inflammation with focus on the GPx1 genotypes. J. Endocrinol. Invest., 2015; 38: 1065-1074

[31] Curran J.E., Jowett J.B., Elliott K.S., Gao Y., Gluschenko K., Wang J., Abel Azim D.M., Cai G., Mahaney M.C., Comuzzie A.G. i wsp.: Genetic variation in selenoprotein $S$ influences inflammatory response. Nat. Genet., 2005; 37: 1234-1241

[32] Bretz J.D., Arscott P.L., Myc A., Baker J.R.Jr.: Inflammatory cytokine regulation of Fas-mediated apoptosis in thyroid follicular cells. J. Biol. Chem., 1999; 274: 25433-25438 
[33] Mezosi E., Wang S.H., Utsugi S., Bajnok L., Bretz J.D., Gauger P.G., Thompson N.W., Baker J.R.Jr.: Interleukin-1 $\beta$ and tumor necrosis factor (TNF)- $\alpha$ sensitize human thyroid epithelial cells to TNF-related apoptosis-inducing ligand-induced apoptosis through increases in procaspase-7 and bid, and the down-regulation of p44/42 mitogen-activated protein kinase activity. J. Clin. Endocrinol. Metab., 2004; 89: 250-257

[34] Wang S.H., Van Antwerp M., Kuick R., Gauger P.G., Doherty G.M., Fan Y.Y., Baker J.R.Jr.: Microarray analysis of cytokine activation of apoptosis pathways in the thyroid. Endocrinology, 2007; 148: 4844-4852

[35] Antonelli A., Ferrari S.M., Giuggioli D., Ferrannini E., Ferri C., Fallahi P.: Chemokine (C-X-C motif) ligand (CXCL)10 in autoimmune diseases. Autoimmun. Rev., 2014; 13: 272-280

[36] Santos L.R., Durães C., Mendes A., Prazeres H., Alvelos M.I., Moreira C.S., Canedo P., Esteves C., Neves C., Carvalho D., Sobrinho-Simões M., Soares P.: A polymorphism in the promoter region of the selenoprotein Sgene (SEPS1) contributes to Hashimoto's thyroiditis susceptibility. J. Clin. Endocrinol. Metab., 2014; 99: E719-E723

[37] Wasniewska M., Vigone M.C., Cappa M., Aversa T., Rubino M., De Luca F., Study Group for Thyroid diseases of Italian Society for Pediatric Endocrinology: Acute suppurative thyroiditis in childhood: Relative frequency among thyroid inflammatory diseases. J. Endocrinol. Invest., 2007; 30: 346-347

[38] De Luca F., Santucci S., Corica D., Pitrolo E., Romeo M., Aversa T.: Hashimoto's thyroiditis in childhood: Presentation modes and evolution over time. Ital. J. Pediatr., 2013; 39: 8

[39] Bonfig W., Gärtner R., Schmidt H.: Selenium supplementation does not decrease thyroid peroxidase antibody concentration in children and adolescents with autoimmune thyroiditis. Sci. World J., 2010; 10: 990-996

[40] Nourbakhsh M., Ahmadpour F., Chahardoli B., Malekpour-Dehkordi Z., Nourbakhsh M., Hosseini-Fard S.R., Doustimotlagh A., Golestani A., Razzaghy-Azar M.: Selenium and its relationship with selenoprotein $\mathrm{P}$ and glutathione peroxidase in children and adolescents with Hashimoto's thyroiditis and hypothyroidism. J. Trace Elem. Med. Biol., 2016; 34: 10-14

[41] Stagnaro-Green A.: Approach to the patient with postpartum thyroiditis. J. Clin. Endocrinol. Metab., 2012; 97: 334-342

[42] Korevaar T.I., Schalekamp-Timmermans S., de Rijke Y.B., Visser W.E., Visser W., de Muinck Keizer-Schrama S.M., Hofman A., Ross H.A., Hooijkaas H., Tiemeier H., Bongers-Schokking J.J., Jaddoe V.W., Visser T.J., Steegers E.A., Medici M., Peeters R.P.: Hypothyroxinemia and TPO-antibody positivity are risk factors for premature delivery: The generation R study. J. Clin. Endocrinol. Metab., 2013; 98: 4382-4390

[43] Thangaratinam S., Tan A., Knox E., Kilby M.D., Franklyn J., Coomarasamy A.: Association between thyroid autoantibodies and miscarriage and preterm birth: Meta-analysis of evidence. BMJ, 2011; 342: d2616
[44] Negro R., Greco G., Mangieri T., Pezzarossa A., Dazzi D., Hassan $\mathrm{H}$.: The influence of selenium supplementation on postpartum thyroid status in pregnant women with thyroid peroxidase autoantibodies. J. Clin. Endocrinol. Metab., 2007; 92: 1263-1268

[45] Mao J., Pop V.J., Bath S.C., Vader H.L., Redman C.W., Rayman M.P.: Effect of low-dose selenium on thyroid autoimmunity and thyroid function in UK pregnant women with mild-to-moderate iodine deficiency. Eur. J. Nutr., 2016; 55: 55-61

[46] Karanikas G., Schuetz M., Wahl K., Paul M., Kontur S., Pietschmann P., Kletter K., Dudczak R., Willheim M.: Relation of anti-TPO autoantibody titre and T-lymphocyte cytokine production patterns in Hashimoto's thyroiditis. Clin. Endocrinol., 2005; 63: 191-196

[47] Pállinger E., Csaba G.: A hormone map of human immune cells showing the presence of adrenocorticotropic hormone, triiodothyronine and endorphin in immunophenotyped white blood cells. Immunology, 2008; 123: 584-589

[48] Rotondi M., Chiovato L., Romagnani S., Serio M., Romagnani P.: Role of chemokines in endocrine autoimmune diseases. Endocr. Rev., 2007; 28: 492-520

[49] Antonelli A., Ferrari S.M., Frascerra S., Di Domenicantonio A., Nicolini A., Ferrari P., Ferrannini E., Fallahi P.: Increase of circulating CXCL9 and CXCL11 associated with euthyroid or subclinically hypothyroid autoimmune thyroiditis. J. Clin. Endocrinol. Metab., 2011; 96: 1859-1863

[50] Antonelli A., Ferrari S.M., Frascerra S., Galetta F., Franzoni F., Corrado A., Miccoli M., Benvenga S., Paolicchi A., Ferrannini E., Fallahi P.: Circulating chemokine (CXC motif) ligand (CXCL)9 is increased in aggressive chronic autoimmune thyroiditis, in association with CXCL10. Cytokine, 2011; 55: 288-293

[51] Antonelli A., Ferri C., Ferrari S.M., Frascerra S., Ruffilli I., Caponi L., Ulisse S., Miccoli M., Miccoli P., Fallahi P.: High levels of circulating chemokine ( $\mathrm{C}-\mathrm{X}-\mathrm{C}$ motif) ligand 11 are associated with euthyroid or subclinically hypothyroid autoimmune thyroiditis and with chemokine (C-X-C motif) ligand 10. J. Interferon Cytokine Res., 2012; 32: 74-80

[52] Antonelli A., Rotondi M., Fallahi P., Romagnani P., Ferrari S.M., Buonamano A., Ferrannini E., Serio M.: High levels of circulating CXC chemokine ligand 10 are associated with chronic autoimmune thyroiditis and hypothyroidism. J. Clin. Endocrinol. Metab., 2004; 89: 5496-5499

[53] Nanba T., Watanabe M., Inoue N., Iwatani Y.: Increases of the Th1/Th2 cell ratio in severe Hashimoto's disease and in the proportion of Th17 cells in intractable Graves' disease. Thyroid, 2009; 19: 495-501

[54] Phenekos C., Vryonidou A., Gritzapis A.D., Baxevanis C.N., Goula M., Papamichail M.: Th1 and Th2 serum cytokine profiles characterize patients with Hashimoto's thyroiditis (Th1) and Graves' disease (Th2). Neuroimmunomodulation, 2004; 11: 209-213

[55] Konca Degertekin C., Aktas Yilmaz B., Balos Toruner F., Kalkanci A., Turhan Iyidir O., Fidan I., Yesilyurt E., Cakır N., Kustimur S., 
Arslan M.: Circulating Th17 cytokine levels are altered in Hashimoto's thyroiditis. Cytokine, 2016; 80: 13-17

[56] Li D., Cai W., Gu R., Zhang Y., Zhang H., Tang K., Xu P., Katirai F., Shi W., Wang L., Huang T., Huang B.: Th17 cell plays a role in the pathogenesis of Hashimoto's thyroiditis in patients. Clin. Immunol., 2013; 149: 411-420

[57] Xue H., Yu X., Ma L., Song S., Li Y., Zhang L., Yang T., Liu H.: The possible role of $\mathrm{CD} 4^{+} \mathrm{CD} 25^{\text {high }} \mathrm{Foxp} 3^{+} / \mathrm{CD} 4^{+} \mathrm{IL}-17 \mathrm{~A}^{+}$cell imbalance in the autoimmunity of patients with Hashimoto thyroiditis. Endocrine, 2015; 50: 665-673

[58] Wichman J., Winther K.H., Bonnema S.J., Hegedüs L.: Selenium supplementation significantly reduces thyroid autoantibody levels in patients with chronic autoimmune thyroiditis: A systematic review and meta-analysis. Thyroid, 2016; 26: 1681-1692

[59] Winther K.H., Wichman J.E.M., Bonnema S.J., Hegedüs L.: Insufficient documentation for clinical efficacy of selenium supplementation in chronic autoimmune thyroiditis, based on a systematic review and meta-analysis. Endocrine, 2017; 55: 376-385 